\title{
The biology and preimaginal morphology of Italian endemic species Isturgia sparsaria (Hübner, 1809) (Lepidoptera, Geometridae)
}

\author{
Hossein Rajaei ${ }^{1}$, Michael Leipnitz ${ }^{2}$, Siegfried OrtneR $^{3}$
}

1 Staatliches Museum für Naturkunde Stuttgart, Rosenstein, 1, 70191-Stuttgart, Germany; hossein.rajaei@smns-bw.de (corresponding author)

2 Bodoweg-8,70327-Stuttgart, Germany; mc.leipnitz@web.de

3 Rettenbachwaldstr.8/1,A4820Bad Ischl, Austria; s.ortner@eduhi.at

http://zoobank.org/B2A524D7-3DEB-4E7C-9354-D7B03D474FCB

Received 20 October 2016; accepted 15 December 2016; published: 3 February 2017

Subject Editor: Sven Erlacher.

\begin{abstract}
The geometrid species Isturgia sparsaria (Hübner, 1809) is restricted to Italy and its biology is unknown. Recently, several individuals of this species have been successfully reared in captivity. Experiments with various potential host plants are reported. The larva was reared successfully on Genista tinctoria L. and Ulex europaeus L. (both from family Fabaceae). Adult insects, as well as ovum, larva, and pupa are illustrated and/or briefly described.
\end{abstract}

\section{Introduction}

Genus Isturgia Hübner, 1823, with around 60 species, is mainly distributed in the Palaearctic, Afrotropical and Oriental Regions, and in Australia (Skou and Sihvonen 2015). Of these, 16 Isturgia species occur in Europe (Flamigni et al. 2007; Skou and Sihvonen 2015). In this genus, the biology and early stages of the Italian species Isturgia sparsaria (Hübner, 1809) (as well as of I. punctistrigaria (Christoph, 1897) and I. messapiaria (Sohn-Rethel, 1929)) were unknown (see Prout 1915; Wehrli 1940; Flamigni et al. 2007; Leraut 2009; Skou and Sihvonen 2015).

Isturgia sparsaria (Figs 1,2) is a medium-sized geometrid moth (wingspan 24-28 mm). Wing colour pale straw, sprinkled with brown, with three brown lines, antemedial angled at costa, obsolescent medial, and postmedial; hindwing with postmedial line (see Flamigni et al. 2007 and Skou and Sihvonen 2015 for further morphological descriptions and diagnostic characters). It is an Adriato-Mediterranean species (corology after Hausmann 2001) endemic to Italy, in most of the Apennine mountain chain, Liguria, and Piedmonte (Skou and Sihvonen 2015).

\section{Material and methods}

On 7 June 2016, the third author collected a female specimen of Isturgia sparsaria in central Italy (Prov. Frosinone, ca. $1 \mathrm{~km}$ NW of Acuto, altitude $770 \mathrm{~m}, 13^{\circ} 09^{\prime} 57.97^{\prime} \mathrm{E}, 41^{\circ} 48^{\prime} 00.11^{\prime \prime} \mathrm{N}$ ).

A single female was attracted to a black light. It laid a total of 71 eggs in a small plastic box, with the bottom covered by toilet paper. Each egg was laid separately. During his holidays in Sardinia, the second author received the eggs from the third author in a plastic box. They were placed in a refrigerator $\left(2^{\circ} \mathrm{C}\right)$ for five days to retard their development until he reached home and 
could start his experiments. Most of the eggs were then kept in the refrigerator $\left(2^{\circ} \mathrm{C}\right)$, but three were allowed to hatch at room temperature $\left(22^{\circ} \mathrm{C}\right)$ in order to conduct experiments on host-plant preferences before allowing the remainder to hatch.

The tiny first instar larvae were housed in a small Polyethylene box $(7.0 \times 4.5 \times 3.0 \mathrm{~cm})$. They were offered a variety of food plants to see which plants were being accepted (this examination took eight days). Then, the larvae were transferred to the food plant. The first instar larva could always be recognised by the bigger head capsule in comparison with the body. After second-third ecdysis, the breeding was continued successfully in a cage $(12 \times 12 \times 25 \mathrm{~cm})$, which was covered with a screen-printing mesh, with the food plant in a small jar of water.

\section{Results and discussion}

Food plants and preimaginal stages. The second author successfully reared the larvae, after many experiments on food preferences (see below).

Food plant. Nearly all species of Isturgia feed on species of Fabaceae (Scoble and Krüger 2002; Flamigni et al. 2007; Skou and Sihvonen 2015). Based on this knowledge, the larvae were offered a wide variety of Fabaceae in our experiments, as well as species in other families (e.g. Lonicera sp.; Artemisia sp.; Prunus sp.) (see Table 1 for the complete list of all tested plants listed by family).

\section{Preimaginal stages}

Ovum. Elliptical, length about $0.75 \mathrm{~mm}$, breadth about $0.45 \mathrm{~mm}$. Freshly laid eggs dark greygreen, becoming violet-brown after two or three days. The eggs were attached dorso-ventrally to the substrate.

Larva. The first and second instar larva (L1 and L2) are more or less grey-green, without any characteristic colour pattern. The colour pattern appears gradually from L3 towards L5 (see below). The fifth instar (L5) (Fig. 3) is $35-45 \mathrm{~mm}$ long ( $\mathrm{n}=6$ ). Larval ground colour light turkey-green with scattered tiny dark dots; dorsal line is slightly darker, bordered on each side with a thin dark line; sub-dorsal and dorso-lateral lines slightly lighter than background, bordered by thin dark lines; lateral black spots, with higher concentration towards head capsule, form a disconnected black line, which becomes blurred in abdominal region; sub-lateral line yellow, ventrally with characteristic black spots, which are clearly visible on segments A3, A4, A5, and A6. Spiracles dark brown. Head white to light straw-coloured, with tiny dots. After 30-35 days and shortly before pupation, the fully-grown larva stops feeding and its ground colour changes to light pink or red-brown (Fig. 4).

Pupa. In total six larvae completed their development to the pupal stage. Pupa 10-11 mm long, fairly scabrous, red-brown in colour; wing case dark-green directly after pupation, gradually becoming dark-brown; punctures visible on $1^{\text {st }-8^{\text {th }}}$ abdominal segment (Fig. 5). Pre-pupal phase lasts four to six days in the soil, under laboratory conditions, and no cocoon was formed.

Results of this study indicate that the larvae feed largely on flowers or young soft leaves of Genista tinctoria and flowers or young soft spines of Ulex europaeus in captivity. It is likely that the hostplant of Isturgia sparsaria in the wild is also a species of Fabaceae. In the locality where the specimens were collected, Spartium junceum (Fabaceae) is quite common and is regarded as a potential hostplant of I. sparsaria in the wild, but this suggestion needs further study. According to 


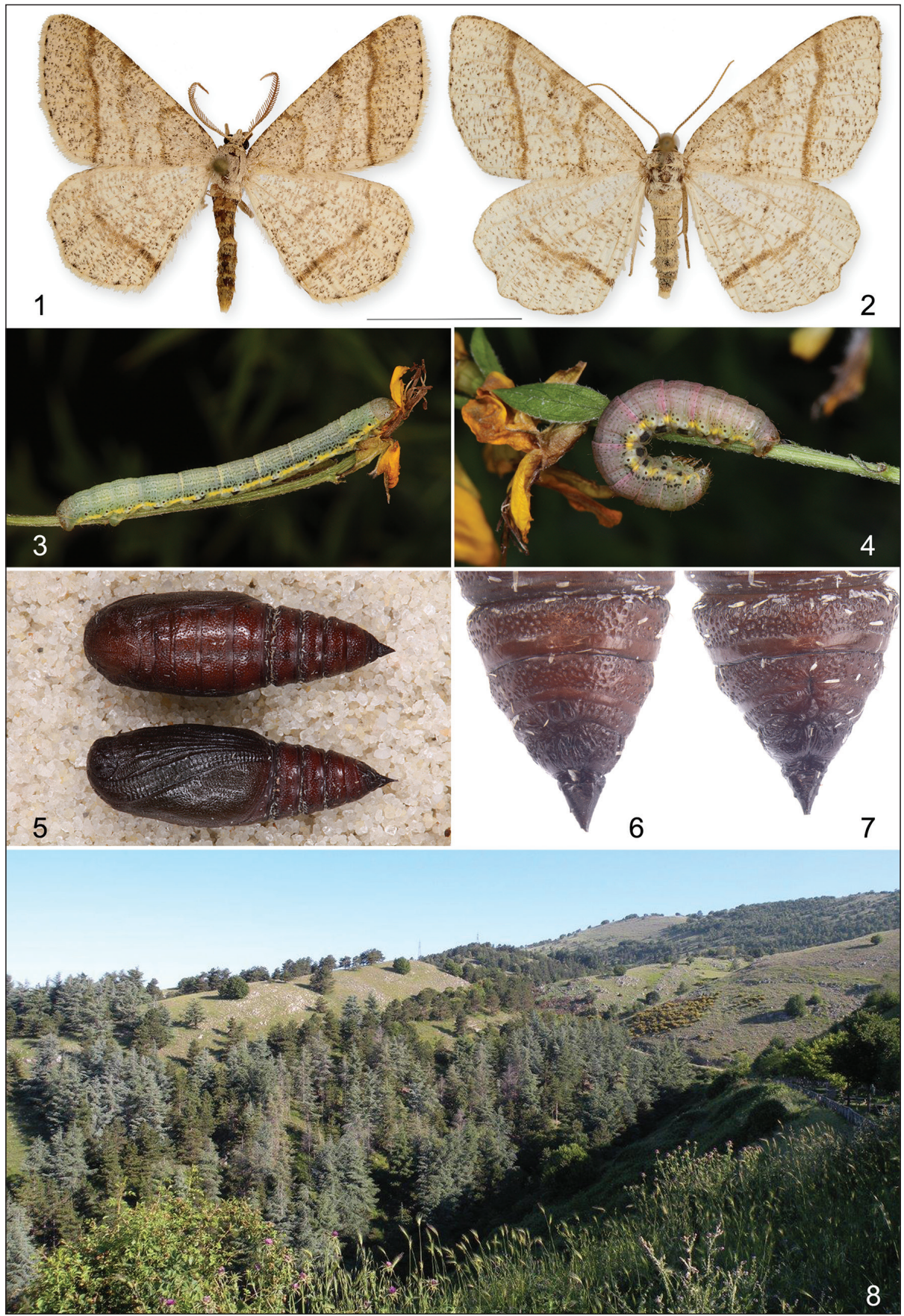

Figures 1-8. 1-6. Isturgia sparsaria. 1. Male (Italy, Marche, Bolognola, 1100 m, Valle Fargno, 2.viii.2010, leg. Teobaldelli, in coll. M. Leipnitz). 2. Female (Italy, Abruzzo, Majella, 450 m, Fara S. Martino, Valle del Fossato, 26.vi.2009, leg. N. Zahm, in coll. M. Leipnitz). 3. Fifth instar larva (L5). 4. Pre-pupal stage. 5. Pupa. 6-7. Pupal cremaster of male (6) and female (7). 8. Habitat of Isturgia sparsaria, where female specimen was collected: Acuto (Italy, Prov. Frosinone, altitude $770 \mathrm{~m}$ ). Scale-bar for Figs 1, 2: $1 \mathrm{~cm}$. 
Table 1. Isturgia sparsaria (Hübner, 1809): larval reactions to plants (listed by family) offered under captive conditions (botanic nomenclature according to The Euro+Med Plant Base: http://www.emplantbase.org/ home.html).

\begin{tabular}{|c|c|}
\hline Family: Plant species & Larval reaction \\
\hline $\begin{array}{l}\text { Fabaceae: } \\
\text { Lathyrus pratensis } \mathrm{L} . \\
\text { - } \\
\text { - } \\
\text { - } \\
\text { - }\end{array}$ & Rejected \\
\hline Fabaceae: Genista tinctoria $\mathrm{L}$. & Accepted (Flowers, young soft leaves) \\
\hline Fabaceae: Ulex europaeus L. & Accepted (Flowers and young soft spines) \\
\hline Salicaceae: Salix purpurea L. & Rejected \\
\hline Fagaceae: Quercus robur L. & Rejected \\
\hline Rosaceae: Prunus spinosa L. & Rejected \\
\hline Apiaceae: Bupleurum falcatum L. & Rejected \\
\hline Lamiaceae: Thymus vulgaris L. & Rejected \\
\hline Caprifoliaceae: Lonicera tatarica L. & Rejected \\
\hline Compositae: Artemisia alba Turra (= A. camphorata Vill.) & Rejected \\
\hline
\end{tabular}

Flamigni et al. (2007), I. sparsaria reaches also higher altitudes (1300 $\mathrm{m}$ and $1600 \mathrm{~m}$ in the central and southern Apennines, respectively), where S. junceum does not occur. However, Genista tinctoria is widespread throughout the Apennine regions from sea level up to $1800 \mathrm{~m}$.

It is also quite possible that the larvae of this species are polyphagous on other plants which occur in its habitat. In captivity, the larvae accepted two different genera of Fabaceae, but further field studies are necessary to confirm how host specific the larvae of this species are in the wild.

As the adult specimens of Isturgia sparsaria were observed on an oak, Quercus sp. (WormHansen 1935), this tree was suggested as a potential hostplant (Flamigni et al. 2007). In our experiments, the larvae rejected Quercus robur and this tree is definitely not one of the hostplants.

\section{Acknowledgments}

Our special thanks go to Dr. Norbert Zahm (Schmelz-Huttersberg) for his useful advice and comments on different literature related to this study and for his help with our bibliographical research. The authors are grateful to Claudio Flamigni and Gary Edward King for their constructive comments to the manuscript. 


\section{References}

Leraut P (2009) Moths of Europe, vol. 2, Geometrid moths. N.A.P. Editions, Verrières le Buisson, France, $808 \mathrm{pp}$.

Prout LB (1912-1916) Die Spanner des Paläarktischen Faunengebietes. In: Seitz A (Ed.) Die Gross-Schmetterlinge der Erde, Vol. 4. A. Kernen, Stuttgart, 1-479.

Wehrli E (1939-1954) Die Spanner des Paläarktischen Faunengebietes. In: Seitz A (Ed.) Die Gross-Schmetterlinge der Erde, Vol. 4, supplement. A. Kernen, Stuttgart, 254-766.

Flamigni C, Fiumi G, Parenzan P (2007) Lepidotteri Eteroceri D'Italia - Geometridae Ennominae I. Natura Edizioni Scientifiche, Bologna, $382 \mathrm{pp}$.

Hausmann A (2001) Introduction, Archiearinae, Orthostixinae, Desmobathrinae, Alsophilinae, Geometrinae. In: Hausmann A (Ed.) The Geometrid Moths of Europe 1. Apollo Books, Stentrup, 1-282.

Skou P, Sihvonen P (2015) Ennominae I. In: Hausmann A (Ed.) The Geometrid Moths of Europe 5. Brill, Leiden, 1-657.

Scoble M, Krüger M (2002) A review of the genera of Macariini with a revised classification of the tribe (Geometridae: Ennominae). Zoological Journal of the Linnean Society 143(3): 257-315. https://doi. org/10.1046/j.1096-3642.2002.00008.x

Worm-Hansen JG (1935) Additional notes on the Lepidopterous fauna of San Cataldo (Southern Italy). Notes from a collecting trip in the spring and early summer of 1931. Entomologiske Meddelelser, København 19: 277-285. 